\title{
Contract Formation and Interpretation
}

\author{
Avery Wiener Katz \\ Georgetown University
}

\begin{abstract}
To appear in the New Palgrave Dictionary of Economics and the Law (The Macmillan Press, forthcoming 1998), Peter Newman, ed.
\end{abstract}

Revised draft, July 24, 1997

Do not quote or cite without author's permission.

\begin{abstract}
Much research in law and economics, following Coase's insight that the effects of a legal rule depend on the ability of those whom it governs to bargain around it, has undertaken to explain how substantive entitlements such as property rights influence the bargaining process. Perhaps more important than any substantive rights or duties in this regard, however, is the extensive body of contract doctrine that governs the procedural mechanics of exchange. The formal rules of contract formation, by attaching consequences to the various acts and omissions that bargainers can choose from in a negotiation, affect the parties' incentives to make and to respond to offers, to delay, to bluff, and to communicate in the first place. Similarly, the law of contract interpretation - ranging from default rules to irrebuttable presumptions - determines the costs of bargaining into and around particular contract terms. Both sets of rules thus influence which contracts get formed and the terms on which they get formed. For these reasons, contract formation and interpretation can fairly be said to be logically prior to every other issue in law and economics. This essay surveys the economic effects of the doctrinal rules of contract formation and interpretation, focusing specially on the incentives such rules provide for strategic behaviour in negotiation. Each of its individual sections discusses a particular aspect of such incentives.
\end{abstract}

As Coase (1960) famously observed, the effects of any legal rule depend on the ability of those whom it governs to bargain around it. His celebrated "theorem," which observes that if bargaining were frictionless and costless, legal rules would have no allocative consequence, is merely a special instance of this general insight. A critical task for those wishing to analyze legal rules and institutions, accordingly, is to explain what the frictions to bargaining are, why they exist, and just how they influence the outcome of exchange. An answer to any of these questions, however, requires some specific account of bargaining.

The modern game-theoretic literature on bargaining casts doubt on the claim, put forward by some of Coase's more sanguine followers, that unregulated actors will tend to bargain toward an efficient outcome. Rather, such a result only holds when individual incentives are properly aligned with the interests of the group as a whole. If individual negotiators can act strategically to alter the distribution of gains from trade (as in Cooter 1982 or Crawford 1982), or if they bargain under asymmetric information (as in Samuelson 1985, Farrell 1987, or Schweizer 1988), they need not reach a first-best or even second-best outcome. The extent of deadweight loss, moreover, depends on the particular institutional arrangements under which negotiation takes place.

Much research in law and economics has accordingly undertaken to explain how substantive rights and duties influence the bargaining process. For example, Cooter (1982) suggests that the contract doctrines of duress and unconscionability are best understood as an attempt to discourage overly aggressive - and hence potentially inefficient - negotiating tactics; and Ulen (1984) proposes that making specific performance the standard remedy for contract breach will improve 
performance decisions by creating both an incentive and a clear framework for bargaining. More recently, a considerable literature has developed on the issue of whether efficient bargaining under asymmetric information is better promoted by property rules or liability rules (see e.g., Ayres and Talley 1995a, 1995b; Kaplow and Shavell 1995).

Perhaps more important than any substantive legal entitlements in this regard, however, is the extensive body of doctrine that governs the procedural mechanics of exchange and that defines when and how the parties' communications interact to create a binding obligation. The formal rules of contract formation, by attaching consequences to the various acts and omissions that individual bargainers can choose from in a negotiation, affect the parties' incentives to make and to respond to offers, to delay, to bluff, and to communicate with one another in the first place. Similarly, the law of contract interpretation - ranging from mere default rules that apply in the absence of explicit agreement to irrebuttable presumptions - determines the costs of bargaining into and around particular contract terms. Both sets of rules thus influence which contracts get formed and the terms on which they get formed. For these reasons, as I have argued elsewhere (Katz 1990a), contract formation and interpretation can fairly be said to be logically prior to every other issue in law and economics.

Contract formation and interpretation rules, furthermore, are the only legal rules that are inherently mandatory. Most substantive entitlements are alienable in Western legal systems, at least for sophisticated commercial actors; and the remainder could become so if the political decision were taken to expand the scope of freedom of contract. But no enforceable agreement to transfer or renounce such entitlements could be possible, even under the most libertarian regime, without some official procedures designated to mark the occasion of an exchange. Even when parties have the leeway to choose what formation and interpretation rules will be applied in their subsequent dealings (for instance, as \$2-209 of the Uniform Commercial Code permits, by agreeing that any modifications to their agreement must be in writing), accordingly, that choice must be implemented under the procedures prevailing at the time they contract, not those that they hope to establish for the future.

The proper economic approach to this field of contract law, however, is the same as with any other legal topic; it is to view legal rules as constraints within which rational individuals maximize the pursuit of their goals. To understand this body of doctrine, it is necessary to look carefully at the ways in which law provides incentives for individuals engaged in a negotiation. This essay, accordingly, surveys the economic effects of the doctrinal rules of contract formation and interpretation, focusing specially on the incentives such rules provide for strategic behaviour in negotiation. Each of the succeeding sections discusses a particular aspect of such incentives.

\section{InCEntives to MaKe AND to Accept OfFers}

Perhaps the most direct way in which the Anglo-American law of contract regulates bargaining is through the cost of making and accepting offers. Various costly formalities, for instance, must be complied with before a contract becomes enforceable. The statute of frauds requires a writing for several important categories of contracts including those that exchange interests in real property. The common-law doctrine of indefiniteness requires certain critical features of the bargain - typically price, quantity, and a reasonably complete description of the subject of exchange - to be spelled out explicitly in advance. Indeed, as Fuller (1941) observed, even the common-law doctrine of 
consideration falls into this category, insofar as it raises the ceremonial threshold for enforcement of promises that do not obviously present a mutual exchange of value.

Many of these requirements have been relaxed over recent decades as part of a more general jurisprudential pattern favoring standards over rules and substance over form; in this regard, the rise of promissory estoppel as a basis for contract liability (see, e.g., Gilmore 1974, Atiyah 1979) has been perhaps the most prominent doctrinal development. At the same time, however, legislatures have increasingly been willing to prescribe new formalities, such as written notice, conspicuous presentation of key terms, and cooling-off periods, in the specialized area of consumer law. Both trends have been the subject of continuing controversy in legal and policy circles. An economic approach to contract formation, however, helps clarify the issues at stake. From the economic perspective, formal requirements such as consideration raise the cost of entering into contracts and thus reduce the number of exchanges entered into. This observation would, by itself, suggest a loosening of those requirements, except that the exchanges so deterred are at the margin of private profitability. To the extent that they entail costs not recognized and internalized by the parties, accordingly, they may be undesirable from a social viewpoint.

The doctrine of silent acceptance (Katz 1990a, 1993) provides a fair illustration of such tradeoffs. The common law generally requires the recipient of a contract offer to respond affirmatively in order to create a binding obligation; silence or inaction operates as an acceptance only in special and limited circumstances. The conventional explanation for these exceptions is that the circumstances indicate that the offeree has consented to be bound, but this explanation conceals an implicit economic logic. Under the common law, two communications are required to form a contract, while only one is needed in interactions that do not result in an exchange. A rule of silent acceptance, conversely, under which the offeree must respond in order to avoid being bound, requires one communication for a contract and two for a rejection. In the usual context where the majority of offers are rejected and the costs of rejections and acceptances are comparable, therefore, the common-law rule conserves on total message costs.

The reason why an additional formal constraint can improve the parties' joint welfare is that the offeror does not fully take into account the offeree's response costs when making an offer. Specifically, the cost of an acceptance, which lowers the price that the offeree is willing to pay, is internalized in the offeror's decision, but the cost of a rejection is not. Indeed, under a silent acceptance regime, the offeror benefits from high rejection costs, which raise both the probability of an acceptance and the price that can be charged. Silent acceptance thus can encourage rent-seeking in the form of opportunistic offers to those with high response costs, deliberate selection of inefficient channels of communication, and the like. Such risks help explain why, for instance, the negative option plans offered by mail-order book and record clubs, in which the seller periodically announces selections to be sent unless the buyer countermands the order, typically provide buyers with substantial up-front benefits.

There are many situations, however, in which construing silence as acceptance would be efficient notwithstanding these strategic hazards. One such circumstance arises when the probability of acceptance is high and the cost of communication modest, so that rent-seeking is not a significant concern. Another is when, due to market failure or other reasons, the quantity of output is too low. In situations of imperfect competition or natural monopoly, for example, a rule of acceptance by 
silence could, by making it harder for buyers to reject offers, help counteract the efficiency loss from supracompetitive pricing. The traditional doctrinal exceptions to the common-law rule, however, do not obviously correspond to these circumstances, and can create inefficiencies of their own. For instance, allowing acceptance by silence between parties with a history of past dealings, while denying it in new relationships, can increase barriers to competitive supply - as recent disputes over the use of so-called "negative option" plans by regulated utilities illustrate (see, e.g., Phillips 1993).

A rule interpreting silence as acceptance, moreover, is open to criticism on grounds of distributional equity even where it promotes efficiency. The gains from the rule are enjoyed primarily by the offeror, who will offer less generous terms under a regime in which it is costly to reject, and by those offerees who attach a relatively high value to exchange. Offerees who attach a relatively low value to exchange are generally made worse off by a silent-acceptance rule, for they are forced to choose between accepting on terms that yield them a negative return and expending resources sending in rejections. In either event such offerees are worse off than if they had just been left alone. The common-law rule, in contrast, blocks this redistribution and ensures that both parties to the exchange share in any surplus.

Many of the considerations raised by the silent-acceptance problem apply in analogous fashion to other doctrinal formalities such as definiteness and consumer warnings. In general, the efficiency of such requirements turns on how the costs of formal compliance compare with the costs of monitoring one's communications to avoid unwanted contractual liability under a less formal regime. Other things being equal, accordingly, it is desirable to reduce formalities if more affected parties prefer to enter into contracts than to avoid them, and if there is little scope for rent-seeking on the part of opportunistic promisees. Conversely, if the cost of avoiding inadvertent or incautious promises is high (as for the overly sentimental, unsophisticated targets of high-pressure salesmen, and similarly vulnerable persons) or if informality imposes externalities on third parties (as with indefinite contracts that consume significant judicial resources for their resolution, and transactions that cloud property rights to the disadvantage of the parties' creditors and other stakeholders), then there is a case for putting some formal barriers in contracting parties' way.

Additionally, just as the law of contract formation imposes formal requirements for those wishing to enter into contracts generally, the law of contract interpretation establishes numerous burdens for those who wish to contract using particular terms. For example, the Uniform Commercial Code requires written warranty disclaimers to be conspicuous (\$2-316) and mandates a separate signature to create certain option contracts $(\$ 2-205)$; it also establishes a number of default rules of interpretation, such as the presumption of cash on delivery in $\$ 2-310$, that oblige parties wishing to provide for different arrangements to do so explicitly. Similarly, the common law requires parties negotiating a written contract to incorporate all prior agreements in the final text if they do not want such agreements disallowed as parol evidence. The principles for analyzing such doctrinal provisions (leaving aside issues of asymmetric information, which are discussed below in section 3) are analogous to those already discussed. As Goetz and Scott (1985) have observed, it is most efficient to establish default rules of interpretation that are in accordance with majority preference, for this conserves on the overall expense of formal contracting For instance, so long as the costs of negotiating and drafting cash and credit terms are comparable, it is cheaper to impose such costs on the minority of traders who want to engage in credit sales than on the majority who want cash sales. Heightened formal requirements may well be in order, however, for those contract terms that are 
offered in a manner that threatens to expropriate rent from offerees, or that impose external costs on third-party competitors or the public system of courts. The first of these concerns is exemplified by courts' traditional suspicion of fine-print disclaimers, the second by doctrines disfavouring firm offers, and the third by the parol evidence rule.

It should be recognized, however, that formal barriers may not be the best method of deterring socially questionable transactions. Anticompetitive behaviour, for instance, may be more sensibly dealt with through the more flexible standards of antitrust's rule of reason, and requiring litigants to pay the full judicial costs of their disputes through a properly calculated user fee is plainly more efficient than requiring them to waste an equivalent amount of real resources in order to receive the services of publicly-subsidized courts.

\section{Incentives to Make Reliance InVestments}

It has been widely recognized (e.g., Williamson 1979) that a central economic function of contract law is to encourage contracting parties to invest in relationship-specific assets. Such specialized investments typically make trade more valuable; but if the underlying exchange is abandoned they will go to waste. As a result, the makers of such investments are vulnerable to ex post holdup — that is, a partner with superior bargaining power can, by demanding a unilateral modification or by insisting on interpreting an ambiguous contract term in his favour, appropriate the bulk of the investment's value for himself. Parties who anticipate such rent-seeking will thus be reluctant to sink resources in such assets without some legal protection on which they can rely. Many substantive contract doctrines, ranging from the traditional common-law's pre-existing duty rule to the modern duty of good faith, are designed to provide precisely this protection.

Such concerns are no less important in the pre-contractual setting. Most exchanges are more valuable when the trading parties can devote the effort needed to determine just what terms are best for their particular circumstances. Because this process takes time, however, reliance opportunities inevitably present themselves after negotiation has begun but before a formal contract can be concluded. Indeed, the resources expended in negotiating with a particular partner are themselves a form of reliance investment, one which in complicated exchanges can amount to a substantial part of the gains from trade. The rules for allocating these costs will influence the course of bargaining, accordingly, and may determine whether negotiation takes place at all.

Moreover, protecting specific investments during precontractual bargaining presents a more difficult problem than protecting them after agreement is completed. While post-agreement holdups can be policed by enforcing the parties' initial bargain in letter or spirit, in the precontractual setting there is no bargain to enforce. For this reason, legal doctrines that attempt directly to regulate rent-seeking in preliminary negotiations, such as the civil law rule of culpa in contrahendo, US labour law's duty to bargain in good faith, and the equitable principle of unconscionability, typically entail close judicial oversight of the substantive terms of trade and depend in practice on individual factfinders' personal views of fair distribution.

The common law, however, generally takes a less interventionist regulatory approach, instead protecting precontractual reliance by making it a relevant factor in determining whether a contract 
has been formed. Most significantly, the doctrine of promissory estoppel, embodied in US law in $\$ 90$ of the Restatement of Contracts, makes such reliance, if reasonably and foreseeably incurred in response to another's promises or representations, a sufficient basis for liability on its own. Craswell (1996) argues, for instance, that the critical factor in courts' willingness to find an offer and acceptance in close cases is whether the parties have relied; according to his survey of the case law, significant but reasonable reliance tends to lead to contractual liability, while either insignificant or excessive reliance does not.

Whether the incentives provided by these doctrines are efficient, however, is a separate question. In any potential exchange only a certain amount of reliance is optimal - the quantity that balances the benefits arising from a marginal increase in investment against the additional increment of waste that will be incurred should the transaction fail to go through. Similarly, because both the productive value of reliance and the level of uncertainty change over time, for any given reliance investment there is an optimal time at which it should be made. Unlimited liability for induced reliance encourages greater case on the part of those who make assurances, but also creates moral hazard for those who rely. So long as a party shares in any of the expected benefits from reliance, insulating her from its costs will encourage her to rely as early and intensively as she can.

As with any problem of bilateral incentives (see Cooter 1985), two alternative strategies are available for promoting optimal reliance in such settings. One approach is for some tribunal typically a court - to evaluate the efficiency of reliance ex post, and to condition liability explicitly on its findings. This approach, advocated by Craswell and implicit in $\S 90$ 's doctrinal requirements that reliance be reasonable and that liability be limited as justice requires, in theory provides both parties with proper incentives. If promisees can recover when (and only when) their reliance decisions fail a cost-benefit test, they will internalize both the costs and benefits of reliance and will be led to choose efficient investments. Promisors, who will then bear any residual costs of lost reliance, will thus face the correct incentives when making representations.

This first approach, however, requires factfinders to measure accurately the costs and benefits of reliance after the fact. Courts are often poorly placed to do this, both because of the practical limitations of the legal process and because reliance decisions frequently turn on noncontractable and nonverifiable information. But they may nonetheless be able to follow the simpler approach of identifying and holding liable the party best able to make and act on such an analysis in the first instance - the so-called "least-cost avoider." Strict liability for the least-cost avoider is a second-best strategy; it abandons the attempt to provide bilateral incentives, but arguably directs the courts' limited enforcement capacity where it is most effective.

This alternate programme can illustrated by the analysis of promissory estoppel in preliminary negotiations. I argue in Katz (1996) that the costs of wasted precontractual reliance are most efficiently assigned, other things being equal, to whichever party has the greater ex post bargaining power (which is itself, inter alia, a function of market structure, information, and the parties' relative rates of risk aversion and time preference). The reasoning is roughly analogous to that of Grossman and Hart's (1986) model of vertical integration: optimal investment incentives require that the costs and benefits of investment be allocated, so far as possible, to the same person. Because the party with greater bargaining power is likely to capture the bulk of the surplus in subsequent contract negotiations, he or she should also bear the losses when no contract is consummated. In the 
precontractual setting, this means holding negotiators to their preliminary offers and representations if, and only if, they hold superior bargaining power. Offerors with bargaining power will then be induced to make such representations carefully and in timely fashion, while those who lack such power will be freed from the risk of subsequent holdup by their offerees. In contrast, the modern rule that relied-upon offers are binding as option contracts whenever the reliance was reasonably to be anticipated (see Restatement of Contracts §87) gives too much power to offerees and puts too much burden on offerors.

Craswell's and my competing arguments extend straightforwardly to analogous contract formation problems such as indefiniteness, the distinction between bilateral and unilateral contracts, and the mailbox rule for contracts concluded by correspondence. They can also be applied to the various interpretative doctrines that are used to fill gaps or resolve ambiguities in the parties' agreement. For instance, courts called upon to enforce a substantive duty of good faith, or to define a reasonable warranty or delivery term, can proceed in one of two ways. They can attempt to perform their own cost-benefit analysis of the issue in question, interpreting the underlying contract to call for what appears to them to be efficient behaviour under the circumstances; alternatively, they can simply interpret the contract in favour of the weaker party in ex post negotiations. The former approach gives both parties good incentives with respect to decisions not explicitly dealt with in the contract, but requires the enforcing tribunal to assess those decisions accurately on the merits. The latter approach sacrifices bilateral incentives, but delegates the responsibility for reaching an efficient substantive outcome to the party with superior bargaining power, who is most likely to reap the benefit from a marginal increase in surplus. In so doing, it also prevents the stronger party from taking advantage of contractual incompleteness to expropriate the weaker party's reliance investments. Depending on the importance of such investment, this may improve the efficiency of exchange for strong and weak alike.

\section{INCENTIVES FOR ACQUISITION AND DisClOSURE OF INFORMATION}

In light of the central role that modern game-theoretic accounts of exchange (e.g., Myerson and Satterthwaite 1983) attach to asymmetric information, the most important effect of contract law may lie in the incentives it provides for information acquisition and disclosure. The mechanical procedures of contract law regulate such behaviour in two ways. First, they condition the existence of an enforceable contract on whether and how much information is disclosed; this approach can take the approach of creating liability where otherwise none would exist (as with the doctrines of promissory and equitable estoppel), granting one or both parties an option to avoid liability (as with the doctrine of mistake), or both (as with fraud, which can operate either as a cause of action or a defence). Second, they make the parties' informational perspective relevant to interpreting their agreement's specific terms. A rule that written contracts are to be interpreted against the drafter, for instance, will have different consequences than one that holds that anyone who signs a contract is charged with the duty to read its provisions.

The informational incentives created by formation rules are illustrated by Richard Craswell's writings on the problem of efficient reliance under asymmetric information. In Craswell (1988), he models this problem as one of optimal precaution - that is, of balancing the social costs of gathering and transmitting information (in his specific model, about the probability of performance) against the 
allocative value such information produces in the form of more efficient reliance investments. From such a perspective, liability for promissory estoppel or for misrepresentation, by internalizing some of the costs of promisee uncertainty, helps to encourage those who have or might acquire information to take into account its social value.

As Craswell's model reveals, however, holding a better informed promisor liable for a less informed promisee's lost reliance does not generally internalize all the costs and benefits of information. The reason is that more accurate information allows the parties not just to avoid wasted reliance investments, but also to profit from productive ones. To the extent that the promisee retains any portion of this profit as consumer or producer surplus, the promisor will have an inadequate incentive to invest in information acquisition and disclosure, since she pays all of the costs of doing so and enjoys only a fraction of the associated benefits. Neither expectation nor reliance damages, at least as conventionally measured, fully internalize these benefits, though reliance damages are better in this regard than no liability at all.

If expectation damages are reinterpreted to include all the productive benefits of optimal reliance, however, they can in theory provide proper informational incentives. One way to do this, subsequently proposed by Craswell (1989), is to measure the promisee's expectation at the value that it would have taken had the promisee chosen the level of reliance that appeared optimal given the promisor's representations. This measure works because it internalizes both the promisee's surplus from optimal reliance as well as any incremental changes in that surplus that result from more accurate information. The administrative demands of this rule, however, are very high, except in the special case (emphasized by Craswell) where the promisor specifically represents that particular reliance investments are desirable and the parties have settled on the terms of exchange. To implement the rule, courts would have to estimate first, the costs and benefits of various reliance investments under counterfactual conditions, second, what surplus would result from those investments, and third, how that hypothetical surplus would be divided among the parties. This third task will be particularly intractable in cases where the parties never agreed on a definite bargain.

For similar reasons, formation defences such as mistake and fraud provide only imperfect incentives for acquisition and disclosure of information. These doctrines effectively give the uninformed party an option to cancel the exchange if it turns out ex post to be unprofitable for him. The penalty thus imposed on the opposing party, however, is only loosely related to the external costs stemming from her misrepresentation or silence. Indeed, if she has made relation-specific investments of her own, her losses from an avoided contract may substantially exceed those of the promisee. The efficiency of such defences, accordingly, may depend on courts' ability to restrict their use to situations where investigation or disclosure has been plainly inadequate.

The informational effect of interpretation rules is most prominently illustrated by Ayres and Gertner's analysis of contractual default rules and gap-fillers (1989, 1992). Ayres and Gertner argue that when information is asymmetric such defaults should not be set in accordance with majority preference (the standard recommendation of prior authors), but instead should be set against the interests of the better-informed party. Their reasoning is that the prospect of having a court supply an unfavourable or even inefficient term — what they label a "penalty default" — will motivate the informed party to come forward with his private information, enabling the bargainers to contract around the default and improve the efficiency of their exchange. For example, they suggest 
that the rule of Hadley v. Baxendale, which limits buyer's expectation damages to an amount that can be reasonably foreseen by the seller, allows sellers to separate out high-damage and low-damage buyers and charge them prices that better reflect costs of service. In addition to eliminating the adverse selection that arises when one group is forced to cross-subsidize the other's purchases, the improved information allows sellers to tailor their precautions better to the buyer's particular needs.

As Johnston (1990) points out, however, such screening does not necessarily have to be carried out by courts applying default rules of interpretation; sellers can also induce buyers to self-select by offering them a menu of potential contracts. Furthermore, as he also argues, penalty defaults will not induce optimal revelation by those who lack bargaining power, as the distributional disadvantage to a weaker party of showing one's cards may be greater than the cost of keeping quiet and suffering the penalty. A buyer who discloses that she has high consequential damages from breach, for instance, also reveals her higher willingness to pay for performance. Depending on the parties' relative bargaining power, this latter revelation can lead to a price increase that outweighs any benefits she would obtain from a fuller expectation remedy. Similarly, as Kronman (1978) and Shavell (1994) argue, some freedom to keep silent may be necessary for parties to be willing to invest in acquiring information in the first place, lest the benefits of that information be expropriated in subsequent bargaining. It is unclear, accordingly, whether penalty defaults are more efficient than majoritarian defaults as a general matter.

Majoritarian default rules, furthermore, do help to address at least some problems of asymmetric information. As I argue in my model of fine-print contracts (Katz 1990b), buyers without bargaining power will be reluctant to spend resources reading and evaluating unfamiliar contract terms, for such expenditures are relation-specific and can be expropriated by the seller ex post. If all provisions of the contract are interpreted literally, accordingly, sellers who wish to offer high quality terms will have no credible way to promise not to sneak disclaimers into the fine print. A legal rule that implies a standard set of terms and requires any disclaimer to be clear and conspicuous, however, can provide such a commitment. So long as the default terms are set at the level that most buyers would prefer, the results will be superior to that of an unregulated market in which fine-print terms are given full effect.

\section{CONCLUSIONS: GAME-ThEORETIC AND TRADITIONAL ANALYSES COMPARED}

Before concluding, two caveats are in order. First, because the predictions of game-theoretic models of bargaining are notoriously sensitive to assumptions about timing, information, and strategy space, applying such models to actual legal institutions may require special qualities of judgment and caution. The law and economics literature on bargaining is a diverse and rapidly growing one; and the foregoing discussion should be taken as illustrative rather than exhaustive. Nonetheless, its overall lesson - that the procedural mechanics of contract formation and interpretation law have real consequences for the outcome and efficiency of exchange - is one that practising lawyers would do well to keep in mind when writing and enforcing contracts..

Second, it is useful to compare our strategic analysis with the view that has more traditionally been taken by legal commentators. In the traditional view, formation and interpretation rules are largely a matter of social convention, promulgated to help contracting parties negotiate by ensuring that they 
attach the same meaning to their objective manifestations. For instance, standard legal authorities explain the rules of acceptance by silence (Williston and Jaeger 1957, pp. 319-21; Corbin and Perillo 1963, p, 414) and the application of promissory estoppel in preliminary negotiations (James Baird $v$. Gimbel Bros., Drennan v. Star Paving) as following from customary social understandings, rather than being based on incentive or efficiency grounds. On such a view, it is more important to have the law in this area settled than settled correctly; and the main criterion for evaluating legal rules is whether they are generally accepted and understood. Like traffic ordinances and similar rules of the road, their main job is to prevent the losses that result from misunderstandings and conflicting expectations.

Traditional legal analysis in these doctrinal areas, accordingly, emphasizes problems of inference and explication: how a given rule might best be applied in concrete situations, how to understand when it applies and when it does not, how it might be reconciled aesthetically with other interpretative principles in the larger legal and social culture. To the extent the commentators do discuss incentives and risk allocation, the focus is on incentives to learn the rules in force, and on allocating the inevitable risks of misunderstanding and miscommunication. Thus it may be said that the traditional approach is generally concerned with coordinating the process of bargaining, whereas in this essay I have primarily focused on regulating that process. This difference in focus brings with it a set of different strategic questions. In game-theoretic terms, regulation is a problem of mechanism design - of creating proper incentives so that the desired outcome becomes an equilibrium. Coordination, on the other hand, is a problem of choosing among multiple equilibria, a task which, as Schelling (1960, pp. 88-98) explains, is solved by finding stable focal points.

It should be apparent, however, that coordination and regulation offer complementary approaches as opposed to contradictory ones. Every coordinating rule or interpretative precedent, because it sets the framework in which the parties bargain, simultaneously operates as a regulation; and every regulation generates a corresponding guide to coordinated behaviour, to the extent that its mandates are understood. The factors relevant to good coordination and good regulation, furthermore, tend to overlap. When designing regulations intended to shape incentives, it is always necessary to consider issues of implementation - how hard the rules will be to predict and apply in practice, and how many mistakes will occur as a result. Such considerations will determine, for instance, whether the regulation should take the form of a rule or a standard (e.g., Kaplow 1992, Baird and Weisberg 1982), as well as its optimal degree of complexity (Kaplow 1995). Conversely, successful coordination becomes easier when the proposed focal point is based on rational regulatory criteria, rather than just being chosen arbitrarily.

To illustrate, one reason it seems natural not to interpret silence as acceptance is that we recognize that in the ordinary case such a convention is likely to be wasteful. Only in contexts where the usual common-law rule is inefficient (for example, in repeated dealings or when there is good reason to encourage further exchange or communication) does silence seem a plausible form of assent. Similarly, treating relied-on promises as binding will be most reasonable as a matter of interpretation precisely where it is reasonable as a matter of incentives - for instance, where the promisor has superior information, bargaining power, or ability to bear risk.

In this way, efficiency provides a focal point that can help to resolve the ambiguities created by multiple interpretative equilibria. This resolution can only occur, however, if the facts that determine 
efficiency are publicly known, and if no alternate focal points are presented by historical experience, aesthetics, or competing ethical norms such as equity. When different interpretative principles point toward different focal points, some deliberate regulatory intervention may be needed if an optimal outcome is to be achieved.

In the end, whether the traditional or the game-theoretic approach to procedural contract law is more useful may depend upon one's institutional role. Ordinary citizens operating under an established legal regime need to internalize the prevailing rules of contract law if they wish to harmonize their plans with those of their counterparts. They will accordingly view legal doctrines not just as constraints, but as norms to be pursued, and will be most interested in the questions of inference and application that traditional commentators emphasize. Persons authorized to make law for the future, in contrast, will find the regulatory perspective a more appropriate guide to action. But even lawmakers cannot afford to ignore the traditional perspective entirely, for no legal directive is clear enough to be self-executing in all contexts. As the modern literature on jurisprudence has underscored (see, e.g., Dworkin 1986), legal rules necessarily depend on society's background principles and understandings to supply their operational meaning. If the rules of contract formation and interpretation are to achieve their intended instrumental purposes, accordingly, those who frame them must take account of the interpretative norms and conventions that remain, by their nature, beyond the control of any single lawmaker. 
REFERENCES

\section{List of statutes cited}

Restatement (Second) of Contracts, §87 (“Option Contracts”) (1979).

Restatement (Second) of Contracts, $\$ 90$ ("Promise Reasonably Inducing Action or Forbearance") (1979).

Uniform Commercial Code § 2-205 ("Firm Offers") (1990).

Uniform Commercial Code § 2-209 ("Modification, Recission and Waiver") (1990).

Uniform Commercial Code $§ 2-310$ (“Open Time for Payment or Running of Credit”) (1990).

Uniform Commercial Code $§ 2-316$ (“Exclusion or Modification of Warranties”) (1990).

\section{List of cases cited}

James Baird v. Gimbel Bros., 64 F 2d 344 (2d Cir. 1933).

Drennan v. Star Paving, 333 P 2d 757 (Cal. 1958).

Hadley v. Baxendale, 9 Exch. 341 (1854).

\section{Bibliography}

Ayres, I. and Gertner, R. 1989. Filling gaps in incomplete contracts: an economic theory of default rules, Yale Law Journal 99: 87-130.

Ayres, I. and Gertner, R. 1992. Strategic contractual inefficiency and the optimal choice of legal rules, Yale Law Journal 101: 729-773.

Ayres, I. and Talley, E. 1995a. Solomonic bargaining: dividing a legal entitlement to facilitate Coasean trade. Yale Law Journal 104: 1027-1117.

Ayres, I. and Talley, E. 1995b. Distinguishing between consensual and nonconsensual advantages of liability rules. Yale Law Journal 105: 235-253.

Baird, D. and Weisberg, R. 1982. Rules, standards, and the battle of the forms: a reassessment of 2-207. Virginia Law Review 68: 1217-1262.

Calabresi, G. and Melamed, A.D. 1972. Property rules, liability rules and inalienability: one view of the cathedral. Harvard Law Review 85: 1089-1128.

Coase, R. 1960. The problem of social cost. Journal of Law and Economics 3: 1-44.

Cooter, R. 1982. The cost of Coase. Journal of Legal Studies 11: 1-29. 
Cooter, R. 1985. Unity in tort, contract, and property: the model of precaution. California Law Review 73: 1-51.

Corbin, A. and Perillo, J. 1963. Corbin on Contracts. St. Paul, MN: West Publishing Co., rev'd edn, 1993.

Craswell, R. 1988. Precontractual investigation as an optimal precaution problem. Journal of Legal Studies 17: 401-436.

Craswell, R. 1989. Performance, reliance, and one-sided information. Journal of Legal Studies 18: $365-401$.

Craswell, R. 1996. Offer, acceptance, and efficient reliance. Stanford Law Review 48: 481-553.

Crawford, V. 1982. A theory of disagreement in bargaining. Econometrica 50: 607-637.

Dworkin, R. 1986. Law’s Empire. Cambridge, Mass.: Belknap Press.

Farrell, J. 1987. Information and the Coase theorem. Journal of Economic Perspectives 1: $113-129$.

Fuller, L. 1941. Consideration and form. Columbia Law Review 41: 799-824.

Goetz, C. and Scott, R. 1985. The limits of expanded choice: an analysis of the interactions between express and implied contract terms. California Law Review 75: 261-322.

Grossman, S. and Hart, O. 1986 The costs and benefits of ownership: a theory of vertical and lateral integration. Journal of Political Economy 94: 691-719.

Johnston, J.S. 1990. Strategic bargaining and the economic theory of contract default rules. Yale Law Journal 100: 615-664.

Kaplow, L. 1992. Rules versus standards: an economic analysis. Duke Law Journal 42: 557-629.

Kaplow, L. 1995. A model of the optimal complexity of legal rules. Journal of Law, Economics, and Organization 11: 150-163.

Kaplow, L. and Shavell, S. 1995. Do liability rules facilitate bargaining? A reply to Ayres and Talley. Yale Law Journal 105: 221-233.

Katz, A. 1990a. The strategic structure of offer and acceptance: game theory and the law of contract formation. Michigan Law Review 89: 215-295.

Katz, A. 1990b. Your terms or mine: the duty to read the fine print in contracts. RAND Journal of Economics 21: 518-537.

Katz, A. 1993. Transaction costs and the legal mechanics of contract formation: when should silence in the face of an offer be construed as acceptance? Journal of Law, Economics, and Organization 9: 77-97.

Katz, A. 1996. The economics of promissory estoppel in preliminary negotiations. Yale Law Journal 105: 1249-1309. 
Kronman, A. 1978. Mistake, disclosure, information and the law of contracts. Journal of Legal Studies 7: 1-34.

Myerson, R. and Satterthwaite, A. 1983. Efficient mechanisms for bilateral trading. Journal of Economic Theory 29: 265-281.

Phillips, O. 1993. Negative option contracts and consumer switching costs. Southern Journal of Economics 60(2): 304-315.

Samuelson, W. 1985. A comment on the Coase theorem. In Game-Theoretic Models of Bargaining, ed. A. Roth, New York: Cambridge University Press.

Schelling, T. 1960. The Strategy of Conflict. Cambridge, Mass.: Harvard University Press, rev'd edn, 1980 .

Schweizer, U. 1988. Externalities and the Coase theorem: hypothesis or result? Journal of Institutional and Theoretical Economics 144: 245-266.

Shavell, S. 1994. Acquisition and disclosure of information prior to sale. RAND Journal of Economics 25: 20-36.

Ulen, T. 1984. The efficiency of specific performance: toward a unified theory of contract remedies. Michigan Law Review 83: 341-403.

Williamson, O. 1979. Transaction-cost economics: the governance of contractual relations. Journal of Law and Economics 22: 233-262.

Williston, S. and Jaeger, W. 1957. A Treatise on the Law of Contracts. Mount Kisco, NY: Baker, Voorhis; 3d edn. 1957. 